\title{
Variabilidade genética de genótipos de bananeira (Musa spp) submetidos ao estresse salino
}

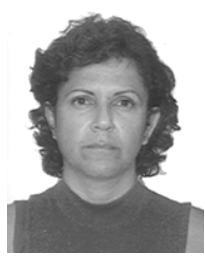

\author{
Eline W. F. Gomes ${ }^{1}$, Lilia Willadino², Luiza S. S. Martins² ${ }^{2}$ Sebastião de O. e Silva4 \& Terezinha R. Câmara ${ }^{3}$ \\ 1 UFRPE. Bolsista DCR - CNPq (Programa de Pós-graduação em Botânica-PPGB). CEP 52171-900 Recife, PE. \\ Fone: (81) 33021366. E-mail: elinewaked@hotmail.com (Foto) \\ ${ }^{2}$ UFRPE. Departamento de Biologia - Fisiologia Vegetal/Genética. CEP 52171-900 Recife, PE, Brasil. Fone: (81) 3302-1366. \\ E-mail: lilia@truenet.com.br; luizasemen@hotmail.com \\ ${ }^{3}$ UFRPE. Departamento de Química - Química Vegetal. CEP 52171-900. Recife, PE. Fone: (81) 3302-1366. \\ E-mail: tcamara@novaera.com.br \\ ${ }^{4}$ EMBRAPA, Mandioca e Fruticultura - CNPMF, CP 007. CEP 44380-000 Cruz das Almas, BA. Fone: (75) 6212149. \\ E-mail: ssilva@cnpmf.embrapa.br
}

Protocolo 58 - 2/4/2003 - Aprovado em 29/10/2004

Resumo: O Brasil é o segundo maior produtor mundial de bananas, sendo Pernambuco o estado que apresenta maior expansão da cultura na região do perímetro irrigado do Vale do São Francisco em cujas áreas, porém, são freqüentes os problemas de salinização do solo o que se pode tornar um fator limitante para a cultura. A utilização de cultivares tolerantes à salinidade apresenta-se como uma alternativa bastante viável; assim, identificar genótipos que se adaptem a solos salinos da Região Nordeste, é de fundamental importância para os programas de melhoramento. Este trabalho teve por finalidade utilizar marcadores moleculares, obtidos por amplificação de DNA via Reação em Cadeia polimerase (PCR) com iniciadores (primers) de RAPD, para determinar a variabilidade genética entre dez genótipos de banana (Musa spp): Pacovan, Nanicão, Caipira, FHIA18, Calcuttá, SN/2, Borneo, M-53, Microcarpa e Lidi, correlacionando-os com a tolerância ao estresse salino. Foram testados 25 primers. O iniciador D0142A07 gerou o maior número de loci polimórficos, enquanto o D0142B05 originou o menor. Em geral, o polimorfismo gerado com os marcadores de DNA mostrou que, apesar da base genética estreita, no caso das que são formadas pelo mesmo grupo genômico, os genótipos de bananeira apresentam variabilidade genética relativamente alta. As variedades que apresentaram maior tolerância ao estresse salino, como a Pacovan e SN/2, mostraram-se distantes geneticamente, quando comparadas com as mais sensíveis ao sal, como Calcuttá e Lidi.

Palavras-chave: salinidade, RAPD, banana

\section{Genetic variability of banana (Musa spp) genotypes subjected to saline stress}

\begin{abstract}
Brazil is the second lagest banana producer. The State of Pernambuco has presented the greatest expansion of banana cultivation in the irrigated perimeters of the São Francisco Valley. In these areas, however, there are frequent problems with high salt content in the soil, which could turn out to be a major limiting factor to its cultivation. The utilization of cultivars tolerant to saline conditions is a rather viable alternative. Thus, identifying genotypes that adapt to the saline soil in the northeast region is fundamental for the genetic improvement. The objective of this study was to utilize molecular markers, obtained by the amplification of DNA via PCR with RAPD primers, in order to assess the genetic variability among ten banana genotypes (Musa spp): Pacovan, Nanicão, Caipira, FHIA18, Calcuttá, SN/2, Borneo, M-53, Microcarpa and Lidi, correlating their tolerance to saline stress. Twenty five primers were tested. The D0142A07 primer generated the greatest number of polymorphic loci, while the D0142B05 generated the lowest. In general, polymorphism generated with the DNA markers showed that, despite the narrow genetic base of those formed by the same genomic group, the banana genotypes exhibited a relatively high genetic variability. The varieties of higher tolerance to saline stress, such as Pacovan and SN/2, proved to be genetically distant when compared to the most salt sensitive, such as Calcuttá and Lidi.
\end{abstract}

Key words: salinity, RAPD, banana 


\section{INTRODUÇÃO}

A cultura da bananeira (Musa spp) é de grande importância na economia mundial, razão por que é cultivada em mais de 100 países, apresentando produção anual superior a 64 milhões de toneladas. O Brasil é o segundo maior produtor de bananas, produzindo 6,4 milhões de toneladas de frutos numa área colhida de 624 mil hectares (FAO, 2002) e, entre as frutas tropicais, é a que apresenta o mais alto índice de consumo per capita. Na Europa, o consumo é de 9,0 kg por habitante ano enquanto no Brasil é de 20,0, sendo considerada a fruta de maior consumo entre os brasileiros (Souza \& Torres Filho, 1999; Rosa Júnior, 2000).

A bananeira é cultivada em todos os Estados brasileiros, sobressaindo-se o Pará como maior produtor, com $771.500 \mathrm{t}$ de frutos, seguido por São Paulo (640.000 t) e Bahia (517.270 t). Pernambuco ocupa a sexta posição, com $360.000 \mathrm{t}$ de bananas produzidas (IBGE, 2002).

Em Pernambuco, a região do perímetro irrigado do Vale do São Francisco apresenta maior expansão da cultura, com 5.500 ha cultivados e uma estimativa, para o ano 2005 , de 9.000 ha (França, 1998); no entanto, essas áreas são propícias à salinidade devido ao manejo deficiente do conjunto águasolo, assim como à qualidade da água e, ainda, às condições de alta evaporação e baixa pluviosidade características da região. A salinidade dos solos é um dos fatores limitantes da cultura da bananeira em virtude da diminuição do potencial osmótico da solução do solo e/ou dos efeitos tóxicos de alguns constituintes iônicos sobre os diversos processos fisiológicos das plantas (Marschner, 1990). A utilização de cultivares tolerantes a tais condições tem-se mostrado uma alternativa viável para a utilização de áreas salinizadas, por se tratar de uma opção de baixo custo e retorno imediato ao agricultor.

O programa de melhoramento genético do Centro Nacional de Pesquisa de Mandioca e Fruticultura Tropical da EMBRAPA, objetiva desenvolver genótipos produtivos, resistentes a pragas e doenças, e com ciclo precoce, mediante cruzamentos entre genótipos diplóides (AA), que contribuem com genes de resistência às diversas doenças e com características agronômicas favoráveis, além de genótipos triplóides (AAB) atualmente cultivados no Brasil (Silva et al., 1999). Segundo Silva (2000) os avanços em programas de melhoramento de bananeira por hibridação, seja para obtenção de híbridos comerciais triplóides ou tetraplóides, dependem basicamente da qualidade dos parentais diplóides, em virtude de seu papel fundamental na incorporação de valores agronômicos. Desta forma, identificar genótipos tolerantes à salinidade é de fundamental importância para cruzamentos que visem à obtenção de variedades adaptadas aos solos salinos da Região Nordeste.

A tolerância à salinidade é uma característica controlada por grande número de genes (herança poligênica) que interagem e contribuem, individualmente, com pequeno efeito no fenótipo (Hurkman, 1992; Jain, 1993; Zhu, 2000). Nestas condições, a identificação de marcadores ligados a esta característica, tornase tarefa difícil, levando-se em conta que a bananeira apresenta um genoma de 537 a 615 Mpb (Lysák, 1999); entretanto, pesquisas em que se utilizaram marcadores moleculares de
DNA na caracterização genética de variedades, possibilitam identificação de germoplasma, seleção de progenitores, predição de heterose, mapeamento de caracteres quantitativos e exploração de loci homólogos em outras espécies, através do mapeamento comparativo, o que permitirá, em trabalhos futuros, mapear os genes ligados à tolerância a salinidade em bananeira.

Nos últimos dez anos, técnicas que possibilitam fazer-se distinção diretamente a nível de DNA, têm permitido, também, que se identifique a variabilidade genética dentro do estoque gênico de espécies cultivadas e avaliar a diversidade disponível em bancos de germoplasma. A técnica que se baseia na detecção de polimorfismo de DNA amplificado ao acaso (RAPD), usando-se oligonucleotídeos decâmeros (dez bases), desenvolvida por Williams et al. (1990), Welsh \& Mc Clelland (1990) e Caetano-Anollés et al. (1991), tem-se mostrado eficiente na identificação da variabilidade genética em diversos grupos de plantas, motivo pelo qual vem sendo usada como ferramenta auxiliar em programas de melhoramento. Esta técnica é também aplicada para obtenção de mapas genéticos (Carrel, 1999; Lagoda, 1999) e identificação de marcadores moleculares úteis na seleção (Milach, 1998). As vantagens do uso desta tecnologia residem no fato de existir um número praticamente ilimitado desses marcadores, os quais não estão sujeitos a efeitos pleiotrópicos, epistáticos ou ambientais apresentando, assim, vantagens em relação a outros marcadores, como os isoenzimáticos ou morfológicos e podem ser determinados em qualquer tipo de tecido ou estádio de desenvolvimento da planta.

A caracterização molecular da diversidade genética pode fornecer dados úteis ao melhorista para a seleção de indivíduos em programas de melhoramento, possibilitando cruzamentos de materiais divergentes, objetivando-se a maximização da distância genética com a finalidade de recombinar genes, ou complexos gênicos, reunindo-os em novas combinações gênicas favoráveis. Marcadores RAPD foram usados por Gawel \& Jarret (1991), Bhat \& Jarret (1995), Carneiro (1997) e Paz (2000), dentre outros autores, com vistas a se detectar variabilidade genética entre grupos genômicos de Musa spp.

Howell et al. (1994) investigando a aplicabilidade de marcadores moleculares RAPD na caracterização de nove genótipos de Musa com genomas AA, AAA, AAB, ABB e BB, verificaram alto grau de polimorfismo e constataram que apenas um dos primers usados seria suficiente para caracterizá-los demonstrando, assim, que nem sempre é necessário se utilizar grande número de iniciadores para avaliar a diversidade genética em germoplasma de bananeira.

Com o presente estudo, objetivou-se utilizar marcadores moleculares obtidos por amplificação de DNA via PCR, com iniciadores (primers) de RAPD, para identificar a variabilidade genética entre dez genótipos de banana (Musa spp) correlacionando-os com tolerância ao estresse salino.

\section{MATERIAL E MÉTODOS}

\section{Condições de plantio e genótipos avaliados}

Implantaram-se dois experimentos para se avaliar o efeito fisiológico-químico de três níveis de $\mathrm{NaCl}(0,50$ e $100 \mathrm{mM}) \mathrm{em}$ 
genótipos de bananeira, em casa-de-vegetação da Universidade Federal Rural de Pernambuco. O primeiro, envolvendo os genótipos: Calcuttá (diplóide selvagem do grupo genômico AA, muito utilizado em programas de melhoramento); as variedades comerciais Pacovan (triplóide do grupo genômico AAB e pertence ao subgrupo Prata) e Nanicão (triplóide AAA, pertencente ao subgrupo Cavendish); Caipira (triplóide AAA) e FHIA 18 (tetraplóide AAAB) que são cultivares indicadas pela EMBRAPA em virtude das suas características agronômicas. O delineamento experimental foi inteiramente casualizado. No segundo experimento foram avaliados os genótipos diplóides (AA) Calcuttá, Borneo, Lidi, SN/2, Microcarpa e M-53 (Tabela 1) e o delineamento experimental utilizado foi o inteiramente casualizado.

Tabela 1. Genótipos diplóides AA provenientes do banco ativo de germoplasma de bananeira da EMBRAPA Mandioca e Fruticultura e suas respectivas origens

\begin{tabular}{llc}
\hline Nome do Genótipo & Origem & Características* \\
\hline Calcuttá & Jamaica & DS S \\
Borneo & Jamaica & DS S \\
Lidi & Honduras & DS P \\
$\mathrm{SN}^{0} / 2$ & Nova Guiné & DS P \\
Microcarpa & Tailândia & DS P \\
M-53 & Equador & DM P \\
\hline * Características: DS - Diplóide Simples; DM - Diplóide Melhorado; S - Produz Semente; \\
P - Partenocárpico
\end{tabular}

As mudas, provenientes de cultura de tecido e adquiridas do Banco Ativo de Germoplasma (BAG) de banana do Centro Nacional de Mandioca e Fruticultura Tropical, da EMBRAPA, foram plantadas em sacos de polietileno contendo $10 \mathrm{~kg}$ de areia lavada. A condutividade elétrica da solução nutritiva dos três tratamentos foi monitorada e mantida na faixa de aproximadamente $1,3-1,7 ; 6,5-6,8$ e 11,3-11,7 dS m $\mathrm{m}^{-1}$, correspondendo às concentrações de 0,50 e $100 \mathrm{mM}$ de $\mathrm{NaCl}$. Utilizou-se irrigação por gotejamento $(0,6 \mathrm{~L}$ por planta dia $)$ com solução nutritiva composta de $742 \mathrm{mg} \mathrm{L}^{-1}$ de fertilizante solúvel (marca Kristalon com 3\% N, 11\% $\mathrm{P}_{2} \mathrm{O}_{5}, 38 \% \mathrm{~K}_{2} \mathrm{O}, 4 \% \mathrm{MgO}$, $11 \%$ S e micronutrientes) e Nitrato de Cálcio (marca Barco Viking com $15,5 \% \mathrm{~N}$ e $19 \% \mathrm{Ca}$ ) na dose de $840 \mathrm{mg} \mathrm{L}^{-1}$ do produto. Após 21 dias de tratamento avaliaram-se os seguintes parâmetros: área foliar e teores de $\mathrm{Na}^{+}$e $\mathrm{Cl}^{-}$no limbo foliar, pseudocaule e raízes+rizoma.

\section{Análises de RAPD}

Extração de DNA: A coleta das terceiras folhas das plantas foi feita aos 21 dias após a diferenciação dos tratamentos. Cerca de $300 \mathrm{mg}$ do limbo foliar foram congelados a $-80^{\circ} \mathrm{C}$ e macerados em almofariz de porcelana, em nitrogênio líquido, segundo metodologia adaptada de Doyle \& Doyle (1990). Ao material macerado adicionaram-se $800 \mu \mathrm{L}$ de tampão de extração (contendo CTAB 5\%; $\mathrm{NaCl}$ 5M; EDTA 0,5M; Tris-HCl 1,0M, $\mathrm{pH} 8,0$; PVP 1\%; $\beta$-mercaptoetanol e $\mathrm{H}_{2} \mathrm{O}$ ). As amostras foram aquecidas a $65^{\circ} \mathrm{C}$, em banho-maria, durante 40 min efetuandose, em seguida, duas lavagens com clorofórmio-álcool isoamílico (24:1) para remoção de proteínas, em centrífuga, durante $5 \mathrm{~min}$, a $14.000 \mathrm{rpm}$; posteriormente, recuperou-se a fase aquosa e se adicionou álcool isopropílico na proporção de 2/3 do volume inicial, para precipitação dos ácidos nucléicos. Após $2 \mathrm{~h}$ de repouso a solução foi centrifugada durante 10 min, a $14.000 \mathrm{rpm}$, cujo precipitado seco foi ressuspendido em $300 \mu \mathrm{L}$ de tampão TE (Tris-HCl $10 \mathrm{mM}$; EDTA $1 \mathrm{mM}$ ajustado a pH 8,0) contendo RNAse $\left(40 \mu \mathrm{g} \mathrm{mL}^{-1}\right)$, a $37^{\circ} \mathrm{C}$, por $30 \mathrm{~min}$. O DNA foi então reprecipitado, adicionando-se-lhe $\mathrm{NaCl} 5 \mathrm{M}$ na proporção 1:10 ( $\mathrm{NaCl}$ : DNA ressuspenso) e 2/3 do volume de isopropanol, incubado a $-20^{\circ} \mathrm{C}$, durante $3 \mathrm{~h}$ para, em seguida, ser centrifugado durante $10 \mathrm{~min}$, a $14.000 \mathrm{rpm}$. O precipitado de DNA seco foi outra vez ressuspenso em tampão TE. A qualidade e a quantidade do DNA extraído foram avaliadas pela eletroforese de $10 \mu \mathrm{L}$ de solução de cada amostra, em um minigel de agarose a $0,8 \%$, e a $80 \mathrm{~V}$, pelo tempo de $30 \mathrm{~min}$, corado com Brometo de etídio e visualizado em ultravioleta.

Reações de amplificação: Na rotina das análises utilizaram-se volumes finais de $25 \mu \mathrm{L}$, que continham os seguintes componentes: DNA $\left(2,5 \mathrm{ng} \mu \mathrm{L}^{-1}\right)$; cada um dos desoxirribonucleotídeos (dATP, dCTP, dGTP, dTTP) $(0,1 \mathrm{mM}) ; \mathrm{MgCl}_{2}$ (2,0 mM); Tris-HCl (10 mM), pH 8,3; um oligonucleotídeo iniciador (0,4 mM) (Gibco BRL) e uma unidade e meia de Taq polimerase (Williams et al.,1990, com modificações). Foram empregados 25 oligonucleotídeos iniciadores, conforme a Tabela 2.

As reações de amplificação foram efetuadas em termociclador M.J. Research, Inc. (USA) PCR, modelo PTC-

Tabela 2. Relação dos oligonucleotídeos iniciadores (primers) e suas seqüências

\begin{tabular}{cc} 
Primers & Seqüências \\
\hline D0142A 01 & AGTCAGCCAC \\
D0142A02 & GTGATCGCAG \\
D0142A03 & CAATCGCCGT \\
D0142A04 & TCGGCGATAG \\
D0142A05 & CAGCACCCAC \\
D0142A06 & TTCCGAACCC \\
D0142A07 & GACCGCTTGT \\
D0142A08 & AGGTGACCGT \\
D0142A09 & CFGCTGGGAC \\
D0142A10 & GTGTGCCCCA \\
D0142A11 & TCAGGGAGGT \\
D0142B01 & GAGCCCTCCA \\
D0142B02 & AGCGTGTCTG \\
D0142B03 & CTGACGTCAC \\
D0142B04 & TGCCCGTCGT \\
D0142B05 & TCGGACGTGA \\
D0142B06 & AGACGTCCAC \\
D0142B07 & ACGCGCATGT \\
D0142B08 & CTGACCAGCC \\
D0142B09 & GGAAGTCGCC \\
D0142B10 & GAAACACCCC \\
D0238C02 & AATCGGGCTG \\
D0238C03 & GAACGGACTC \\
D0238C04 & GACGGATCAG \\
D0238C05 & \\
\hline & \\
\hline &
\end{tabular}


100, utilizando-se um programa composto por 40 ciclos de uma etapa de desnaturação a $94{ }^{\circ} \mathrm{C}$, durante $15 \mathrm{~s}$, uma etapa de anelamento do iniciador ao DNA molde a $35^{\circ} \mathrm{C}$, por $30 \mathrm{~s}$, e uma etapa de extensão a $72{ }^{\circ} \mathrm{C}$, pelo tempo de um minuto; por fim, utilizou-se um ciclo final de $72{ }^{\circ} \mathrm{C}$, por $7 \mathrm{~min}$. Os produtos das amplificações foram separados por eletroforese, a $100 \mathrm{~V}$ por $4 \mathrm{~h}$, em gel de agarose $1,2 \%$, contendo $10 \mu \mathrm{g} \mathrm{mL}^{-1}$ de brometo de etídio, imerso em tampão TBE (Tris-Borato 90 mM; EDTA 1 $\mathrm{mM}, \mathrm{pH} 8,0$ ). As bandas de DNA foram visualizadas sob luz ultravioleta e fotografadas com câmera Polaroid.

Os produtos de amplificação (bandas de DNA) foram tabulados conforme a presença (1) ou ausência (0). As similaridades genéticas entre os genótipos foram estimadas através do coeficiente de Dice (equivalente ao índice de Nei \& Li, 1979), no programa NTSYS - pc (Numerical Taxonomy and Multivariater Analysis System, versão 1,70, Exeter software, N.Y., USA). O dendrograma foi construído no programa NTSYS - pc usando-se a opção UPGMA ("Unweighted Pair - Group Method, Aritmetic Average").

\section{RESULTADOS E DISCUSSÃO}

Dos vinte e cinco primers testados, vinte e três forneceram produtos nítidos de amplificação (D0142A01, D0142A02, D0142A03, D0142A04, D0142A05, D0142A06, D0142A07, D0142A08, D0142A09, D0142A10, D0142B01, D0142B02, D0142B03, D0142B04, D0142B05, D0142B06, D0142B07, D0142B08, D0142B09, D0142B10, D0238C02, D0238C03, D0238C04) e foram considerados neste trabalho para o cálculo de similaridade genética entre os genótipos. O padrão eletroforético obtido com primers de RAPD é ilustrado na Figura 1.
D0142A09

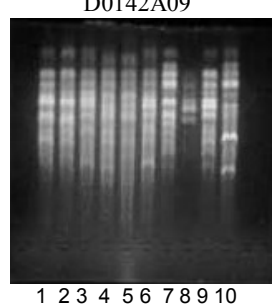

D0142B06

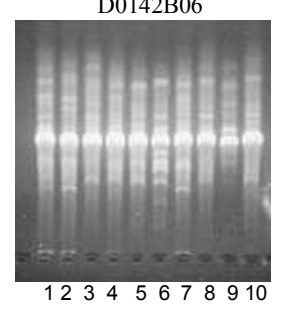

D0142B08

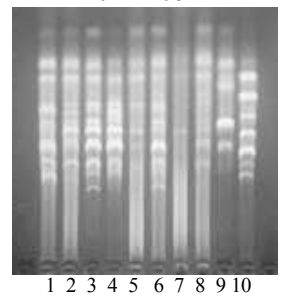

Figura 1. Padrões eletroforéticos obtidos pela amplificação do DNA em genótipos de Musa spp: Pacovan (1), Nanicão (2), Caipira (3), FHIA18 (4), SN/2 (5), Borneo (6), Microcarpa (7), M-53 (8), Calcuttá (9) e Lidi (10)

\section{Primeiro experimento: Caracterização dos genótipos Calcuttá, Pacovan, Nanicão, Caipira e FHIA 18}

Foram amplificadas 354 regiões de bandas das quais 7 $(1,9 \%)$ loci monomórficos e $347(98,1 \%)$ polimórficos obtendo-se, em média, 15,4 loci por primer. O iniciador D0142A07 originou o maior número de loci polimórficos, no total de 22, enquanto o iniciador D0142B05 gerou apenas 7 loci polimórficos.
De acordo com os dados gerados entre os genótipos testados, tomados 2 a 2 (Tabela 3), o par mais próximo geneticamente foi o tetraplóide FHIA 18 e o triplóide Nanicão, com grau de similaridade 0,764 (76,4\%), enquanto os mais distantes foram o diplóide Calcuttá e o triplóide Pacovan, com grau de similaridade 0,467 (46,7\%).

Tabela 3. Similaridades genéticas entre os genótipos: Nanicão, Pacovan, Caipira, Calcuttá e FHIA 18, estimadas através do coeficiente de Dice

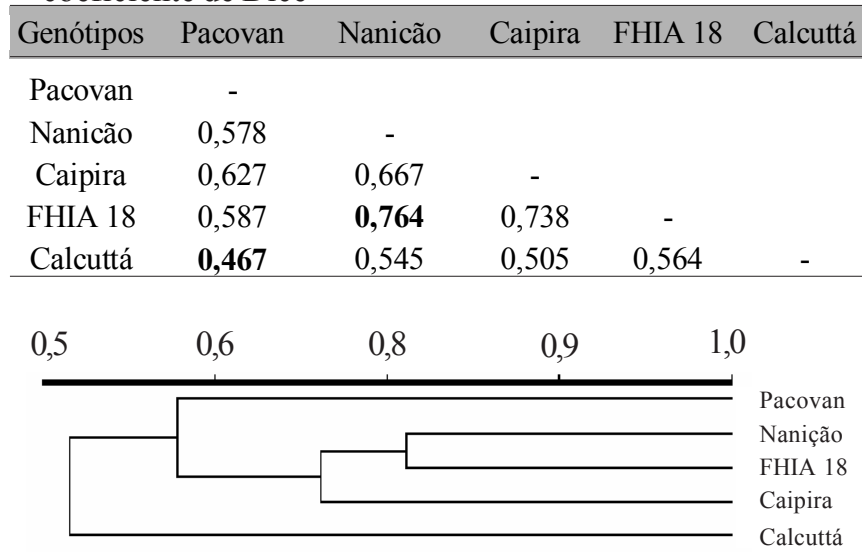

Figura 2. Dendrograma dos genótipos de Musa spp, construído a partir dos produtos de amplificação obtidos com os primers de RAPD, usando-se o método de agrupamento UPGMA

O dendrograma construído permitiu a identificação de dois grupos, um formado pelo genótipo Calcuttá e o outro composto pelos três subgrupos: Pacovan; Nanicão e FHIA 18; Caipira (Figura 2).

Correlacionando-se os dados do efeito do $\mathrm{NaCl}$ nas variedades estudadas (Tabelas 4 e 5) constata-se que a análise de agrupamento separou os genótipos Pacovan, Nanicão, FHIA 18 e Caipira, do genótipo Calcuttá, mais sensível à salinidade e que apresentou elevada redução da área foliar $(49,64 \%)$ e o maior teor de sódio e cloro nas folhas, no tratamento com 100 $\mathrm{mM}$. Esta variedade apresentou, também, teor de sódio nas folhas, oito vezes superior ao controle, demonstrando ausência de habilidade em regular a concentração de sódio neste órgão.

Com relação ao cloro, ocorreu aumento da concentração deste íon em todos os genótipos, em função do incremento da salinidade, com destaque para o diplóide Calcuttá que apresentou a mais alta concentração de cloro quando submetido ao tratamento com $100 \mathrm{mM}$. As variedades Pacovan, Caipira e FHIA 18 mantiveram os mais baixos níveis deste ânion nas

Tabela 4. Área foliar de cinco genótipos de bananeira submetidos a três níveis de $\mathrm{NaCl}$, na fase inicial de desenvolvimento ${ }^{1}$

\begin{tabular}{clllll}
\hline $\begin{array}{c}\mathrm{NaCl} \\
(\mathrm{mM})\end{array}$ & \multicolumn{1}{c}{ Caipira } & \multicolumn{1}{c}{ Pacovan } & \multicolumn{1}{c}{ Calcuttá } & \multicolumn{1}{c}{ FHIA } & Nanicão \\
\cline { 2 - 6 } & \multicolumn{5}{c}{ Área foliar $\left(\mathrm{cm}^{2}\right)$} \\
\hline 0 & $2,676 \mathrm{aB}$ & $5,134 \mathrm{aA}$ & $3,992 \mathrm{aA}$ & $4,778 \mathrm{aA}$ & $5,389 \mathrm{aA}$ \\
50 & $2,259 \mathrm{abB}$ & $3,724 \mathrm{bAB}$ & $2,853 \mathrm{bAB}$ & $2,458 \mathrm{bAB}$ & $4,094 \mathrm{bA}$ \\
100 & $2,003 \mathrm{bB}$ & $3,650 \mathrm{bA}$ & $2,010 \mathrm{bB}$ & $2,325 \mathrm{bB}$ & $2,926 \mathrm{cAB}$ \\
\hline
\end{tabular}

${ }^{1}$ Os valores seguidos da mesma letra minúscula na mesma coluna ou maiúscula na mesma linha, não apresentam diferença significativa pelo teste de Tukey a nível de $5 \%$ de probabilidade 
Tabela 5. Teores de sódio e cloro no limbo foliar, pseudocaule e raízes + rizoma em cinco genótipos de bananeira, submetidos a três níveis de $\mathrm{NaCl}^{1}$

\begin{tabular}{|c|c|c|c|c|c|c|c|c|c|}
\hline \multirow{3}{*}{ Variedades } & \multicolumn{3}{|c|}{ Limbo Foliar } & \multicolumn{3}{|c|}{ Pseudocaule } & \multicolumn{3}{|c|}{ Raízes + rizoma } \\
\hline & \multicolumn{9}{|c|}{$\mathrm{NaCl}(\mathrm{mM})$} \\
\hline & 0 & 50 & 100 & 0 & 50 & 100 & 0 & 50 & 100 \\
\hline Caipira & $3,5 \mathrm{aB}$ & $5,1 \mathrm{bA}$ & $6,5 \mathrm{cA}$ & $1,6 \mathrm{aB}$ & $10,4 \mathrm{aA}$ & $15,4 \mathrm{aA}$ & $2,9 \mathrm{bB}$ & $8,8 \mathrm{aA}$ & $12,9 \mathrm{aA}$ \\
\hline Pacovan & $3,2 \mathrm{aB}$ & $5,3 \mathrm{bA}$ & $6,3 \mathrm{cA}$ & $2,1 \mathrm{aB}$ & $9,2 \mathrm{abA}$ & $10,8 \mathrm{bA}$ & $4,6 \mathrm{aB}$ & $10,0 \mathrm{aA}$ & $15,4 \mathrm{aA}$ \\
\hline Calcuttá & $3,8 \mathrm{aC}$ & $18,1 \mathrm{aB}$ & $28,0 \mathrm{aA}$ & $1,6 \mathrm{aC}$ & $7,9 \mathrm{bB}$ & $13,8 \mathrm{aA}$ & $2,9 \mathrm{bB}$ & $9,2 \mathrm{aA}$ & $15,4 \mathrm{aA}$ \\
\hline \multirow[t]{2}{*}{ Nanicão } & $3,5 \mathrm{aC}$ & $5,8 \mathrm{bB}$ & $14,9 \mathrm{bA}$ & $1,7 \mathrm{aB}$ & $12,1 \mathrm{aA}$ & $12,5 \mathrm{aA}$ & $4,7 \mathrm{aB}$ & $13,3 \mathrm{aA}$ & $16,7 \mathrm{aA}$ \\
\hline & \multicolumn{9}{|c|}{$\mathrm{Cl}^{-}\left(\mathrm{g} \mathrm{kg}^{-1}\right)$} \\
\hline Caipira & $3,3 \mathrm{aB}$ & $40,6 \mathrm{aA}$ & $42,2 \mathrm{bcA}$ & $4,0 \mathrm{aB}$ & $53,4 \mathrm{aA}$ & $62,1 \mathrm{aA}$ & $3,5 \mathrm{aB}$ & $41,4 \mathrm{aA}$ & $49,7 \mathrm{aA}$ \\
\hline Pacovan & $3,9 \mathrm{aB}$ & $31,4 \mathrm{aA}$ & $34,3 \mathrm{cA}$ & $4,8 \mathrm{aB}$ & $37,6 \mathrm{bA}$ & $42,6 \mathrm{aA}$ & $5,7 \mathrm{aB}$ & $41,8 \mathrm{aA}$ & $45,9 \mathrm{aA}$ \\
\hline Calcuttá & $4,9 \mathrm{aC}$ & $35,2 \mathrm{aB}$ & $66,2 \mathrm{aA}$ & $3,1 \mathrm{aB}$ & $44,3 \mathrm{abA}$ & $49,3 \mathrm{aA}$ & $5,3 \mathrm{aB}$ & $45,1 \mathrm{aA}$ & $50,5 \mathrm{aA}$ \\
\hline
\end{tabular}

'Os valores da mesma coluna seguidos da mesma letra minúscula em cada variável ou na mesma linha, seguidos da mesma letra maiúscula, não apresentam diferença significativa, pelo teste de Tukey a nível de $5 \%$ de probabilidade

folhas, no mesmo tratamento. Em função da transpiração, tende a ocorrer acúmulo de íons nas folhas, sobretudo quando o genótipo não possui mecanismos de exclusão dos íons tóxicos. O mecanismo geralmente envolve a compartimentalização dos íons a nível de órgão (raiz) ou a nível celular (vacúolo). Quando a acumulação de íons excede a capacidade de tolerância da planta, ocorrem danos, como cloroses e necroses. Esses sintomas foram observados principalmente na Calcuttá, que sofreu os maiores danos nas folhas e as maiores concentrações de $\mathrm{Na}^{+}$e $\mathrm{Cl}^{-}$no limbo foliar. No que se refere aos teores de sódio e cloro nas raízes+rizoma e no pseudocaule, praticamente não houve diferença significativa entre os genótipos quando considerado o mais alto nível de $\mathrm{NaCl}(100 \mathrm{mM})$.

\section{Segundo experimento: Caracterização dos genótipos Diplóides Calcuttá, Borneo, Lidi, SN/2, Microcarpa e M-53}

Os primers utilizados amplificaram 393 loci gênicos, sendo $37(9,4 \%)$ monomórficos e $356(90,6 \%)$ polimórficos. Os iniciadores D0142A04 e D0238C03 geraram maior número de loci polimórficos, no total de 9 loci.

A análise da matriz de similaridade genética e do dendrograma (Tabela 6 e Figura 3) permitiu que se identificassem dois grupos entre os seis acessos avaliados. Grupo I, formado pelos genótipos SN/2, Borneo, Microcarpa e M-53, e grupo II, composto por Calcuttá e Lidi. O grupo II associa os acessos que se apresentaram menos tolerantes ao $\mathrm{NaCl}$, enquanto o grupo I reúne acessos mais tolerantes ao estresse salino. O maior e o menor grau de similaridade genética foram observados entre os acessos Borneo e SN/2 (72,6\%) e entre
Tabela 6. Similaridades genéticas entre os genótipos: SN/2, Borneo, Microcarpa, M-53, Calcuttá e Lidi, estimadas através do coeficiente de Dice

\section{SN/2 Borneo Microcarpa M53 Calcuttá Lidi}

\section{$\mathrm{SN} / 2$}

\begin{tabular}{lcccccc} 
Borneo & $\mathbf{0 , 7 2 6}$ & - & & & & \\
Microcarpa & 0,660 & 0,679 & - & & & \\
M-53 & 0,675 & 0,623 & 0,646 & - & & \\
Calcuttá & 0,573 & 0,545 & 0,559 & $\mathbf{0 , 5 1 2}$ & - & \\
Lidi & 0,590 & 0,547 & 0,533 & 0,580 & 0,691 & - \\
\hline
\end{tabular}

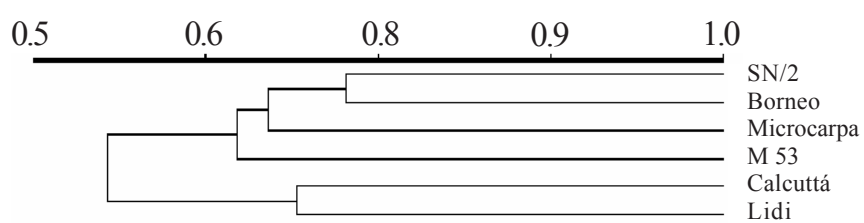

Figura 3. Dendrograma dos genótipos de Musa spp, construído a partir dos produtos de amplificação obtidos com os primers de RAPD, usando-se o método de agrupamento UPGMA

Calcuttá e M-53 (51,2\%), respectivamente. Os genótipos Calcuttá e Borneo, ambos originários da Jamaica (Tabela 1), mostraram baixa similaridade genética $(54,5 \%)$, cujo resultado sugere que os acessos se originam de diferentes locais de coleta.

Cada um dos dois grupos formados pela análise de agrupamento, contém genótipos que compartilham características químicas e fisiológicas. Quanto ao efeito da salinidade sobre o crescimento (Tabela 7), constata-se que o

Tabela 7. Área foliar de seis genótipos de bananeira submetidos a três níveis de $\mathrm{NaCl}^{1}$

\begin{tabular}{|c|c|c|c|c|c|c|}
\hline \multirow{2}{*}{$\begin{array}{l}\mathrm{NaCl} \\
(\mathrm{mM})\end{array}$} & $\mathrm{SN} / 2$ & Borneo & Calcuttá & Microcarpa & M-53 & Lidi \\
\hline & \multicolumn{6}{|c|}{ Área foliar $\left(\mathrm{cm}^{2}\right)$} \\
\hline 0 & $6,233 \mathrm{aA}$ & $5,029 \mathrm{aAB}$ & $6,280 \mathrm{aA}$ & $5,100 \mathrm{aAB}$ & $3,520 \mathrm{aB}$ & $5,013 \mathrm{aAB}$ \\
\hline 50 & $5,135 \mathrm{abA}$ & $4,020 \mathrm{abABC}$ & $4,404 \mathrm{abAB}$ & $3,800 \mathrm{abABC}$ & $2,303 \mathrm{abC}$ & $3,217 \mathrm{abBC}$ \\
\hline 100 & $2,924 \mathrm{bAB}$ & $2,634 \mathrm{bAB}$ & $3,405 \mathrm{bA}$ & $2,507 \mathrm{bAB}$ & $1,297 \mathrm{bB}$ & $1,889 \mathrm{bB}$ \\
\hline
\end{tabular}


grupo I associou os acessos mais tolerantes ao estresse salino e, conseqüentemente, os que apresentaram no tratamento com $50 \mathrm{mM}$, menores reduções de área foliar (Borneo e SN/2); o grupo II é formado pelos genótipos mais sensíveis à presença do $\mathrm{NaCl}$ que apresentaram as maiores reduções de área foliar.

Quanto ao acúmulo de íons (Tabela 8) constatou-se, no tratamento com $100 \mathrm{mM}$, que no grupo II se associaram os genótipos (Calcuttá e Lidi) que acumularam mais sódio e cloro no limbo foliar e, ainda, apresentaram sintomatologia de clorose e queima nas folhas. No pseudocaule essas duas variedades apresentaram novamente os maiores teores de sódio, quando submetidas a $100 \mathrm{mM}$ de $\mathrm{NaCl}$.

$\mathrm{O}$ alto grau de polimorfismo, detectado com os marcadores de RAPD, está de acordo com os observados por Shepherd et al. (1986), Gawel \& Jarret (1991), Howell et al. (1994), Carneiro (1997) e Paz (2000), dentre outros. Bhat \& Jarret (1995) afirmaram que a ampla variabilidade entre diplóides selvagens do grupo AA pode ser atribuída ao efeito de repetidas seleções ou mutações nos clones cultivados, que têm resultado em genoma de Musa acuminata, significativamente diferente daquele encontrado em seus ancestrais diplóides. Jarret \& Gawell (1995), usando a técnica de RAPD na caracterização de clones de plátanos e na avaliação da diversidade genética entre diplóides de $M$. acuminata, concluíram que esta técnica pode disponibilizar informações sobre vários aspectos da diversidade genética em germoplasma de bananeira.

Considerando-se o nível de ploidia dos genótipos estudados no primeiro experimento (Figura 1), vê-se que o dendrograma separou o diplóide AA dos demais com nível de ploidia maior. Dos três acessos triplóides, Nanicão (AAA) e Caipira (AAA) se agruparam, apresentando similaridade genética em torno de $66,7 \%$ atribuída, provavelmente, à presença do mesmo grupo genômico acuminata (A) presente nos materiais. Quando se comparam os triplóides Pacovan (AAB) com Caipira (AAA) ou Nanicão (AAA), observa-se diminuição no grau de similaridade, indicando que o grupo genômico balbisiana (B), presente na Pacovan, diferencia os genomas das mesmas. A formação de grupos distintos na análise de agrupamento dos genótipos diplóides AA do segundo experimento é função, provavelmente, de mutações existentes nesses genomas, fixadas pelo processo de seleção natural ou resultante de processos de melhoramento genético.

\section{CONCLUSÕES}

1. Em geral, o polimorfismo gerado com os marcadores de DNA mostrou que, apesar da base genética estreita, no caso das que são formadas pelo mesmo grupo genômico, os genótipos de bananeira apresentam variabilidade genética relativamente alta.

2. As variedades que apresentaram maior tolerância ao estresse salino, quando comparadas com as mais sensíveis ao sal, mostraram-se distantes geneticamente.

\section{LITERATURA CITADA}

Bhat, K.V.; Jarret, R.L. Random amplified polimorphic DNA and genetic diversity in Indian Musa germplasm. Genetic Resources and Crops Evolution, Netherlands, v.42, n.2, p.328-332, 1995.

Caetano-Anollés, G.; Bassam, B.J.; Gresshoff, P.M. High resolution DNA amplificaction fingerprinting using very short arbitrary oligonucleotide primers. Bio Technology, Oxford, v.9, p.553-557, 1991.

Carneiro, M.S. Aplicabilidade de marcadores "Random Amplified Polymorphic DNA" (RAPD) para monitoramento da variação somaclonal em bananeira do subgrupo Cavendish. Cruz das Almas: UFBA, 1997, 61p. Dissertação Mestrado

Tabela 8. Teores de íons na folha, pseudocaule e raízes + rizoma em seis genótipos diplóides de bananeiras, submetidos a três níveis de $\mathrm{NaCl}^{1}$

\begin{tabular}{|c|c|c|c|c|c|c|c|c|c|}
\hline \multirow{3}{*}{ Variedades } & \multicolumn{3}{|c|}{ Limbo Foliar } & \multicolumn{3}{|c|}{ Pseudocaule } & \multicolumn{3}{|c|}{ Raízes + Rizoma } \\
\hline & \multicolumn{9}{|c|}{$\mathrm{NaCl}(\mathrm{mM})$} \\
\hline & 0 & 50 & 100 & 0 & 50 & 100 & 0 & 50 & 100 \\
\hline Lidi & $3,0 \mathrm{aC}$ & $11,8 \mathrm{aB}$ & $23,2 \mathrm{aA}$ & $1,9 \mathrm{aC}$ & $10,1 \mathrm{aB}$ & $18,4 \mathrm{aA}$ & $4,0 \mathrm{aB}$ & $6,2 \mathrm{aB}$ & $13,2 \mathrm{aA}$ \\
\hline Microcarpa & $3,8 \mathrm{aB}$ & $7,0 \mathrm{aAB}$ & $10,2 \mathrm{bA}$ & $1,6 \mathrm{aC}$ & $5,0 \mathrm{bB}$ & $10,7 \mathrm{bA}$ & $4,0 \mathrm{aB}$ & $7,5 \mathrm{aB}$ & $10,0 \mathrm{aA}$ \\
\hline $\mathrm{SN} / 2$ & $3,0 \mathrm{aA}$ & $5,0 \mathrm{aA}$ & $6,4 \mathrm{bA}$ & $1,6 \mathrm{aC}$ & $8,2 \mathrm{abB}$ & $12,5 \mathrm{bA}$ & $4,0 \mathrm{aB}$ & $8,8 \mathrm{aA}$ & $10,8 \mathrm{aA}$ \\
\hline \multirow[t]{2}{*}{ M-53 } & $3,4 \mathrm{aA}$ & $5,6 \mathrm{aA}$ & $7,8 \mathrm{bA}$ & $1,3 \mathrm{aC}$ & $8,4 \mathrm{abB}$ & $12,3 \mathrm{bA}$ & $3,4 \mathrm{aB}$ & $7,9 \mathrm{aA}$ & $11,5 \mathrm{aA}$ \\
\hline & \multicolumn{9}{|c|}{$\mathrm{Cl}^{-}\left(\mathrm{g} \mathrm{kg}^{-1}\right)$} \\
\hline Lidi & $10,6 \mathrm{aC}$ & $35,0 \mathrm{aB}$ & $51,5 \mathrm{aA}$ & $9,5 \mathrm{aB}$ & $36,6 \mathrm{aA}$ & $47,1 \mathrm{aA}$ & $12,4 \mathrm{aB}$ & $33,5 \mathrm{aA}$ & $36,6 \mathrm{aA}$ \\
\hline $\mathrm{SN} / 2$ & $6,7 \mathrm{aC}$ & $19,8 \mathrm{aAB}$ & $30,9 \mathrm{bA}$ & $6,5 \mathrm{aB}$ & $25,4 \mathrm{aAB}$ & $41,0 \mathrm{aA}$ & $4,4 \mathrm{aB}$ & $35,3 \mathrm{aA}$ & $43,4 \mathrm{aA}$ \\
\hline M-53 & $9,2 \mathrm{aB}$ & $21,0 \mathrm{aAB}$ & $24,8 \mathrm{bA}$ & $8,0 \mathrm{aB}$ & $24,6 \mathrm{aAB}$ & $32,9 \mathrm{aA}$ & $9,9 \mathrm{aB}$ & $41,6 \mathrm{aA}$ & $42,8 \mathrm{aA}$ \\
\hline
\end{tabular}


Carrel, F. Genome mapping and genetic analysis of the black leaf streak resistance in bananas. Infomusa, Montpellier, v.8, n.1, p.20-22, 1999.

Doyle, I.J.; Doyle, J.L. Isolation of plant from fresh tissue. Focus, Rockville, v.12, p.13-15, 1990.

FAO. Statistics. agricultural. production. Crops. Primary. Disponível em: http://www.fao.org. Acesso junho 2002.

França, J.G.E. de. Situação atual e perspectiva das áreas irrigadas no Estado de Pernambuco. Petrolina: EMBRAPA, 1998. 121p.

Gawel, N.; Jarret, R.L. Cytoplasm diversity in banans and plantains. Euphytica, Dordrecht, v.52, n.3, p.19-23, 1991.

Howell, E.C.; New Bury, H.J.; Swennwn, R.L.;Whiters, L.A.; Ford-Lloyd, B.V. The use of RAPD for identifying and classifying Musa germplasms. Genome, New York, v.37, n.2, p.328-332, 1994.

Hurkman, W.J. Effect of salt stress on plant gene expression: a review. Plant and Soil, Dordrecht, v.146, n.12, p.145-151, 1992.

IBGE. Estatística. Agricultura. Disponível em: http:// www.sidra.ibge.gov.br. Acesso maio 2002.

Jain, S.; Nainawatee, H.S.; Jain, R.K.; Chowdhury, J.B. Salt tolerance in Brassica juncea L> II: salt-stress induced changes in polypeptide pattern of in vitro selected $\mathrm{NaCl}-$ tolerance plants. Euphytica, Wageningen, v.65, n.2, p.107112, 1993.

Jarret, R.L.; Gawel, N. Molecular markers, genetic diversity and systematics in Musa. In: GOWEN, S. Bananas and plantains: London: Chapman \& Hall, 1995. p.66-83.

Lagoda, P. Mapping and genomics. The study of the Musaceae: mapping and genomics. Infomusa, Montpellier. v.8, n.1, p.6-8. 1999.

Lysák, M.A.; Doleze Lová, M.; Horry, J.P.; Swennen, R.; Dolezel, J. Flow cytometric anlysis of nuclear DNA content in Musa. Theoretical and applied genetics, New York, v.98, n.8, p.1344$1350,1999$.
Marschner, H. Mineral nutrition of higher plants. 4.ed. Belfast: University Press, $1990.674 \mathrm{p}$.

Milach, S.C.K. Marcadores de DNA. Aplicações no melhoramento de plantas. Ed.Sandra Cristina Kothe Milach. Porto Alegre, 1998. 141p.

Paz, O.P. Caracterização de germoplasma de bananeira com RAPD. Cruz das Almas: UFBA, 2000, 67p. Dissertação Mestrado

Rosa Júnior, C.D.R.M. Bananeira. Cultivo sob condição irrigada. Recife: SEBRAE/PE, 2000.51p.

Shepherd, K.; Dantas, J.L.L.; Alves, E.J. Melhoramento genético da bananeira. Informe Agropecuário, Belo Horizonte, v.12, n.72, p.11-19, 1986.

Silva, S. de O. Melhoramento genético de bananeira. Simpósio Brasileiro de Melhoramento de Fruteiras 2, 2000, Viçosa; Anais... Bruckner, C.H. (ed). Viçosa: UFV, DFT; 2000. p.2048.

Silva, S. de O.; Carvalho, P.C.L. de; Shepherd, K.; Alves, E.J.; Oliveira, C.A.P. de; Carvalho, J.A.B.S. Catálogo de germoplasma de bananeira (Musa spp). Cruz das Almas, BA: EMBRAPA Mandioca e Fruticultura, 1999. 152p. Documento, 90.

Souza, J.S.; Torres Filho, P. Aspectos socioeconômicos. In: Alves, E.J. (ed). A cultura da banana. Aspectos técnicos socioeconômicos e agroindustriais. Brasília, D.F.: Embrapa -SP, 1999. p.507-524

Welsh, J.; Mc Clelland, M. Fingerprinting genomes using PCR with arbitar primers. Nucleic Acids Research, Oxford, v.18, p.7213-7218, 1990.

Williams, J.K.G.; Kubeli, K.J.; Rafalski, J.A.; Tingey, S.V. DNA polymorphisms amplified by arbitrary primers are useful as genetic markers. Nucleic Acids Research, Oxford, v.18, p.6531-6535. 1990.

Zhu, J.K. Genetic analysis of plant salt tolerance using Arabidopsis. Plant Physiology, Rockville, v.124, n.3, p.941957, 2000. 